\title{
Anatomical considerations on sira in Ayurveda with special reference to Sushruta Samhita
}

\author{
Review Article
}

\begin{tabular}{c} 
Kumar BMN ${ }^{1 *}$, Awasthi $\mathbf{H H}^{\mathbf{2}}$ \\
1. Asstt.Professor, 2. Professor \& Head \\
Dept. of Rachana Sharir, Faculty of Ayurveda, IMS, BHU \\
\hline
\end{tabular}

\begin{abstract}
The Sushruta samhita is one of the three great treatises (Brihattrayi) of Ayurveda representing mainly the school of surgery. Sushruta samhita as the best one in Sharira (sārire Sushrutah śreșthah). Sushruta has clarified the details such as distinction among sira,dhamani and srotas. The term sira, in one place reflects a meaning of blood vessels while at other place, it means nerve. In such condition it is very difficult to know doubtlessly about it like Modern Anatomy. Therefore, it requires great research work to get a clear concept. Aims and objectives- 1) To search and find out the references in relation to sira in Sushruta samhita. 2) To understand the concept of sira in Sushruta samhita and correlate with Modern Anatomy. Methods: - Ancient Ayurvedic classics were consulted and compiled references out of them for said subject to elaborate as well as to understand the process of sira in Sushruta samhita. Important observations: - Scattered references are available in Sushruta samhita and Modern Anatomy texts regarding sira. Results: - In Sushruta samhita sira is elaborated nicely it can be concluded and correlate with blood vessels, lymphatics and nerves in Modern Anatomy.
\end{abstract}

Key words: Sira,Dhamani,Artery, Vein,Sushruta,Srotas

\section{Introduction}

The Sushruta samhita is one of the three great treatises (Brhattrayi) of Ayurveda representing mainly the school of surgery. Sushruta samhita as the best one in Sharira (śārire Sushrutah śreșthah). Anatomy being the basis of surgery probably it was necessary for Sushruta to deal anatomical details before preparing for surgery. It is also possible that the knowledge of Anatomy got more advanced during the period of Sushruta. Before Sushruta in Vedic times, the knowledge of

*Corresponding Author:

\section{B.M.N.Kumar}

Assitant Professor

Deptt.of Rachana Sharir,

Faculty of Ayurveda, IMS, BHU,

Varanasi

E mail -drbmnkbhu123@gmail.com,

Mobile no-09889988839
Anatomy was derived from the dissection of animals during sacrifices. In Brahmanas and Kalpasutras, we find names of a number of organs which are similar in human body. Sushruta was the first scholar scientist who described the method of the dissection of human cadaver and emphasised on the importance of dissection in study of Anatomy (1). Though it was also crude it may be taken as a historical land mark in the development of Anatomy in India and a clear step of advancement in the knowledge of Anatomy. That's why he is regarded as the father of Anatomy and the Sushurut samhita as the best one in Sharira. Dr.B.G.Ghanekar says Sharira of his is the best and not lost, but it is only difficult to interpret. Sushruta has explained Anatomy of sira in Sharira sthana $7^{\text {th }}$ chapter "Siravarna Vibhakta Nama Shariram". Sushruta's concepts of 
"Sira Shariram" and "Sira vedhyavidhi Shariram" are specifically unique. But the term sira, in one place reflects a meaning of blood vessels while at other place, it means nerve. In such condition it is very difficult to know doubtlessly about it like Modern Anatomy.

Aims and objectives-

1) To search and find out the references in relation to sira in Sushruta samhita.

2) To understand the concept of sira in Sushruta samhita and correlate with Modern Anatomy.

\section{Materials and Methods:}

The Literary material related to sira has been collected from Different sthans (parts) of Sushruta samhita and Modern Anatomy books like Chaurasia General Anatomy, Gray's Anatomy etc. critically reviewed and correlated with modern terms.

\section{Discussion:}

It is said that the word sira derived from the Vedic term hira. The term hira is described as blood carrying channel towards the heart (2). Ayurvedic acharyas has used an anatomical term sira, which is one of the controversial term (structure). It is used to represents tubular structure, to carry material such as Rasa \& Rakta and it is one of the synonyms of srotas (3). Sushruta has clarified the details such as distinction among sira, dhamani and srotas. In $9^{\text {th }}$ chapter of Sharira sthana "Dhamani Shariram Vyakaranam" Sushruta speaks more clearly, he says that "some says that there is no difference among sira, dhamini and srotas, as dhamini and srotas are only sira vikara. This is not correct. Dhamini and srotas are the entities other than sira." (4)

Sushruta has given the 4 reasons for differentiation of these three structures. These are (5)

1) Vyanjanayatvat (different features) By difference in features siras are of various colours like crimson red, white, blue and red. Whereas there is no such differentiation in dhaminis and Srotas.

2) Mulasanniyamat (originating point) By originating point original siras are 40, whereas dhamanis and srotas are 24 and 22 respectively.

3) Karmavisesyat (specific functions) By specific functions sira by their contractility and dilatory property, supply nutrition to the body. Dhamanis carry sensation of sound, vision, taste, smell etc., while Srotas carry air, water, food, rasa etc.

4) Agamcca (scriptural authority) -By scriptural authority, treatises of Ayurveda have mentioned sira, dhamani and srotas separately at many places. Hence dhamani and srotas are different from sira.

These structures look similar because (6)

1. Paraspara sannikarshata (mutual proximity) -Sira, dhamani and srotas are lies very close in the body. Veins and arteries along with their branches are found side by side closely, in all the parts of the body.

2. Sadhrusyagama (similar authority)Due to the transport of the rasa, there is no distinct difference between sira, dhamani and srotas. In Ayurveda, these three terms are used for each other inter changeable. Veins and arteries are identical because all these are hollow tubes.

3. Sadhrusya karma (similar function) Common function of these three structures are transport of doshas and dhatus.Along with functional similarity, there is also some anatomical similarity. All these three structures are elements of akash (ether).

4. Sukshamat (minuteness) -Due to its minute nature the differentiation is difficult. This means that the lack of knowledge of vaidyas and common 
men in general about those minute structures makes them a like.

\section{Anatomical Considerations on Sira in Sushruta Samhita}

In Sushruta samhita sira has been used in two purposes-in general sira has been used to denote the vessels otherwise in specific sense sira means veins. He includes artery, vein, capillary and lymphatics in sira. Apart from this in Sushruta samhita, in some references like sira marma, sira has been used to denote the nerve.

\section{Origination of Sira}

According to Sushruta sira originate in the embryonic life from nabhi (umbilicus) and they spread upward, downward and in oblique fashion from nabhi (umbilicus) (7) .This statement of Sushruta is accepted only during embryonic life. In foetus it can be seen also, that number of veins are attached to umbilicus. In the fetal life the siras are concerned with the nutrition of the foetus through the umbilical cord, but after birth these sira no more exist. Sushruta has labeled them "Nabhiprabhava" because either they start or end in nabhi(umbilicus) in uterine life. Thus Sushruta's description regarding the origin of sira seems to be correct (8).

\section{Structure of Sira}

According to Sushruta Structure of siras are like the fine fibers in the leaf of a tree, thick at their roots and becoming finer towards the end, the branches of the sira resemble the tendrils, the first branch gives out a branch and this again gives out another branch and so on. The blood flows in all the sira which are "like water channels going out to the different areas of a garden or agricultural field (9).

Modern Anatomy of sira also considered same regarding structure. Large arteries leave the heart and branch into smaller ones that reach out to various parts of the body. These divide still further into smaller vessels called arterioles that penetrate the body tissues. Within the tissues, the arterioles branch into a network of microscopic capillaries. Substances move in and out of the capillary walls as the blood exchanges materials with the cells. Before leaving the tissues, capillaries unite into venules, which are small veins. The venules merge to form larger and larger veins that eventually return blood to the heart. The walls of arteries, veins, and capillaries differ in structure. In all three, the vessel wall surrounds a hollow center through which the blood flows. The walls of both arteries and veins are composed of three coats, but they differ in thickness. The inner and middle coats of arteries are thicker than those of veins. This makes arteries more elastic and capable of expanding when blood surges through them from the beating heart. The walls of veins are more flexible than artery walls. This allows skeletal muscles to contract against them, squeezing the blood along as it returns to the heart. One-way valves in the walls of veins keep blood flowing in one direction. The walls of capillaries are only one cell thick. Of all the blood vessels, only capillaries have walls thin enough to allow the exchange of materials between cells and the blood. (10)

\section{General Function of Sira}

As a garden or a grain field is made wet by the water carrying big and small channels, similarly the sira by their contractility and dilatory property, supply nutrition to the body (11). The blood vessels of the body (arteries, capillaries, and veins) make up a closed system of tubes that carry blood from the heart to tissues all over the body and then back to the heart. Arteries carry blood away from the heart, while veins carry blood toward the heart. (12) Here dilation and contraction is the function of arteries. Sympathetic and parasympathetic nerves 
are responsible for vasodilatation and vasoconstriction. Because of pulsation the blood circulates all over the body. In nutrition process of the body all the three blood vessels takes part. Lymphatics also take part in nutrition and they circulate lymph.

\section{Classification of Sira}

Siras are classified into 4 types. These are vatavaha siras,pittavaha siras, kaphavaha siras and raktavaha siras. In these four types of siras every type of sira has specific character, colour and function.

Table 1: showing character, colour and function of four types of siras (13).

\begin{tabular}{|l|l|l|l|l|}
\hline $\begin{array}{l}\text { Type of } \\
\text { sira }\end{array}$ & Colour & Character & Function & $\begin{array}{l}\text { Modern } \\
\text { correlation(14) }\end{array}$ \\
\hline $\begin{array}{l}\text { satavaha } \\
\text { Aruna } \\
\text { varna } \\
\text { (crimson } \\
\text { red) }\end{array}$ & $\begin{array}{l}\text { Filled with } \\
\text { vayu }\end{array}$ & $\begin{array}{l}\text { Perform physical functions } \\
\text { without hindering the specific } \\
\text { functions of buddhi (intellect) } \\
\text { and sense organs. }\end{array}$ & $\begin{array}{l}\text { Arteries } \\
\text { Nerves }\end{array}$ \\
\hline $\begin{array}{l}\text { Pittavaha } \\
\text { siras }\end{array}$ & $\begin{array}{l}\text { Neela } \\
\text { (blue) }\end{array}$ & Warm touch & $\begin{array}{l}\text { Creates lusture in the body and } \\
\text { develops good appetite. }\end{array}$ & Veins \\
\hline $\begin{array}{l}\text { Kaphavaha } \\
\text { siras }\end{array}$ & $\begin{array}{l}\text { Gowra } \\
\text { varna } \\
\text { (white) }\end{array}$ & $\begin{array}{l}\text { Cold to touch } \\
\text { and steady }\end{array}$ & $\begin{array}{l}\text { Gives lubrication to the various } \\
\text { body parts and produces } \\
\text { firmness in the joints. It also } \\
\text { improves strength. }\end{array}$ & Lymphatic \\
\hline $\begin{array}{l}\text { Raktavaha } \\
\text { siras }\end{array}$ & $\begin{array}{l}\text { Rohini } \\
\text { varna } \text { (red }\end{array}$ & $\begin{array}{l}\text { Neither they } \\
\text { are too hot } \\
\text { nor too cold }\end{array}$ & $\begin{array}{l}\text { Nourishes the dhatus improves } \\
\text { the complexion definite } \\
\text { perception of sparsha. }\end{array}$ & Capillaries \\
\hline
\end{tabular}

\section{IMPORTANT SIRAS IN THE BODY}

Sushruta has explained some important siras in the body under the heading of Avedhaya sira and Sira marma.

\section{Avedhya Sira}

Some siras are not suitable for venepuncture .These siras are called Avedhya sira. A surgeon should not perform venesection on this siras would definitely cause disability or death. Among seven hundred sira only 98 sira are considered as Avedhya sira. Remaining can be choosing for venepuncture in certain diseases (15).

Table 2: showing siras which should not be punctured

\begin{tabular}{|l|l|l|l|}
\hline Regions/ locations & Numbers & Sanskrit names & $\begin{array}{l}\text { According to } \\
\text { Dr.B.G.Ghanekar (Sushruta } \\
\text { sharirasthana commentary) } \\
\text { modern correlation of } \\
\text { Avedhya sira (16) }\end{array}$ \\
\hline $\begin{array}{l}\text { Sakthies /bahu } \\
\text { (upper and lower limbs ) }\end{array}$ & $8+8$ & $\begin{array}{l}\text { (i)jaaladhara } \\
\text { (ii) urvi } \\
\text { (iii) lohitaksha }\end{array}$ & $\begin{array}{l}\text { Great sephanous veins, } \\
\text { femoral vessels, cephalic } \\
\text { veins, brachial vessels, } \\
\text { axillary vessels }\end{array}$ \\
\hline
\end{tabular}




\begin{tabular}{|c|c|c|c|}
\hline $\begin{array}{l}\text { Shroni(inguinal and } \\
\text { gluteal region) }\end{array}$ & 8 & $\begin{array}{l}\text { (i)Vitapa (inguinal } \\
\text { or groin) } \\
\text { (ii) Katikataruna }\end{array}$ & $\begin{array}{l}\text { spermatic vessels } \\
\text { Gluteal vessels }\end{array}$ \\
\hline Parshva (flanks) & 4 & - & $\begin{array}{l}\text { There is no such big artery } \\
\text { and vein in the lateral side of } \\
\text { the body. }\end{array}$ \\
\hline Prishtha vansha & 2 & Brihati & Subscapular artery \\
\hline $\begin{array}{l}\text { Udara (above the penis } \\
\text { and the side of romaraji) }\end{array}$ & 4 & - & Inferior epigastric vessels \\
\hline Vaksha (thorax/ chest) & 14 & $\begin{array}{l}\text { (i)Hridaya } \\
\text { (ii)Stanamoola } \\
\text { (iii)Stanarohita } \\
\text { (iv)Apalapa }\end{array}$ & $\begin{array}{l}\text { Intercostal vessels } \\
\text { Internal mammary vessels } \\
\text { Lateral thoracic vessels }\end{array}$ \\
\hline Greeva (neck) & 16 & $\begin{array}{l}\text { (i)Ashta-matrika } \\
\text { (ii)Krikatika } \\
\text { (iii)Vidhur }\end{array}$ & $\begin{array}{l}\text { External, internal carotid } \\
\text { arteries and jugular veins. } \\
\text { Occipital vessels } \\
\text { Posterior auricular vessels }\end{array}$ \\
\hline $\begin{array}{l}\text { Hanusandhigata } \\
\text { (tempero-mandibular } \\
\text { joint) }\end{array}$ & 4 & - & Internal maxillary vessels \\
\hline Jihva (tongue) & 4 & $\begin{array}{l}\text { (i)Rasavaha } \\
\text { (ii)Vakvaha }\end{array}$ & Profunda lingulae vessels \\
\hline Nasa (nose) & 5 & (i)Aupnasika & Angular vessels \\
\hline Talu (palate) & 2 & Talu sira & Palatine vessels \\
\hline Netra (eyes) & 2 & Apanga sira & Zygomatico -temporal vessels \\
\hline Karna (ears) & 2 & Shabdavahi sira & Anterior tympanic vessels \\
\hline $\begin{array}{l}\text { Lalata- nasa- netra } \\
\text { gata(vessels located in } \\
\text { forehead but runs towards } \\
\text { the nose and eyes orbit) }\end{array}$ & 5 & $\begin{array}{l}\text { (i) Keshantanugata } \\
\text { sira (hairline ) } \\
\text { (ii) Aavarta } \\
\text { (iii)Sthapani }\end{array}$ & $\begin{array}{l}\text { The nasal branch of frontal } \\
\text { vein and branches of } \\
\text { superficial temporal arteries. } \\
\text { Frontal branch of superficial } \\
\text { temporal vein. }\end{array}$ \\
\hline Shankha (temporal) & 2 & $\begin{array}{l}\text { Sankhasandhigata } \\
\text { sira }\end{array}$ & $\begin{array}{l}\text { Superficial temporal vessels } \\
\text { in the temporal region. }\end{array}$ \\
\hline Murdha (head) & 8 & $\begin{array}{l}\text { (i) Utkshepa } \\
\text { (ii) Seemanta } \\
\text { (iii)Adhipati }\end{array}$ & $\begin{array}{l}\text { Parietal branch of superficial } \\
\text { temporal vessels. } \\
\text { Branches of occipital and } \\
\text { superficial temporal vessels. }\end{array}$ \\
\hline
\end{tabular}

\section{Sira Marma}

The word Marma has been used in the classical as well as non-classical books. It is as old word as Vedas. It seems that Acharyas have described the regional anatomy in relation to surface anatomy of 
Marma. The word Marma means vital spot in the body. According to Dalhana, the commentator of Sushruta samhita, Marma is that spot where if any injury or trauma is made ,causes death(17).According to Sushruta Marma is the vital spot in the body where confluence of mans (muscles),sira (blood vessels), snayu (ligaments), asthi (bones) and sandhi (joints) present. In these places prana resides specially by nature, therefore any trauma on any one of these Marmas invariably causes death (18). Total numbers of Marmas are 107.According structure he was classified Marmas into 5 types. In this one variety is Sira Marma, these are 41. These are-

- Niladhamani-4

- Matrika-8

- Srngataka-4

- Apanga-2

- Sthapani-1

- Phana-2

- Stanamula-2

- Apalapa-2

- Apastambha-2

- Hridaya-1

- Nabhi-1

- Parsvasandhi-2

- Brhati-2

- Lohitaksha-4

- Urvi-4

The main symptoms of Marma injuries are bleeding and unconscious. In this contest Sushruta said that - "there are four types of siras in the body. They generally lie in the site of Marmas and supply nutrition to snayu (ligaments), asthi (bones), mans (muscles), and thus maintain the body. When Marmas are injured the vayu is increased and encircles the siras, it causes severe pain. Because of this, pain consciousness is gradually lost" (19). Here sira is the structure that gives nutrition to the body and maintains the body. Same point is noted in Modern science ever structure in the body receives blood supply for nutrition and nerve supply for motor and sensory functions. Every structure is supplied by neurovascular bundle; it contains artery, vein and nerve. In sira marma concept all these structures are considered under the term of sira.

\section{Conclusion}

The term Sira stands for channels through which substances or physical forces flow. In general, this term stands for blood vessels, even though Sushruta has also used it in the sense of nerves (vatavaha siras). In modern Anatomy the Vatavaha Siras can be put under the arteries and nerves. The Pittavaha Siras can be accepted as veins and Kaphavaha Siras can be considered as lymphatic channels and Raktavaha Siras are correlated with capillaries of the body.

Modern correlation of four types of siras -

$>$ In Vatavaha siras seeing the colour aruna varna (crimson red) and character filled with vayu (pulsation) denotes that in Modern Anatomy these two are characters of artery. If see the function maintaining the intellect and sense organs suggests that in Modern science these functions are generally performed by nervous system.

In Pittavaha siras seeing the colour neela varna (blue), it suggests that in Modern science veins are blue in colour because these carry deoxygenated blood.

In Kaphavaha siras seeing the colour gowra varna (white), it suggests that in 
Modern science lymphatics are white in colour because these carrying clear fluid lymph.

$>$ In Rakthavaha siras seeing the colour rohini (red) and function nourishes the dhatus, it suggests that in Modern science capillaries are red in colour and exchange the nutrients in tissue level.

In Ayurvedic classics the nervous system has not been described but the functions of the nervous system have been described through the blood vessels. The vayu which circulates in the blood vessels has been held responsible for performing the functions of nervous system. So it seems that Sushruta includes the nervous network in the vascular system. So the word Sira is correlated with the blood vessels and lymphatics is not farfetched and fanciful.

\section{Refrences:}

1. Srikantha Murthy K.R., Sushruta Samhita with English translation, Third edition, Varanasi ,Chaukhambha Orientalia Publishers, 2007, VolumeI:9 p.

2. Gananath Sen Saraswathi, Sanjna Pancake Vimarsha, Reprinted edition, Varanasi, Krishnadas Academy Publishers, 1993, 53 p.

3. Jadavaji Trikanji Acharya, Charaka Samhita with the Ayurveda dipika commentary of Chakrapanidatta, Reprint edition, Varanasi, Chaukhambha Orientalia Publishers, 2009, 285 p.

4. Thatte D.G., Sushruta Samhita with English translation, IInd edition, Varanasi, Chaukhambha Orientalia Publisher, 2007, Volume-III: 166 p.
5. Sharma P.V., Sushruta Samhita text with English translation and Dalhana's commentary, Reprinted edition, Varanasi, Chaukhambha Visvabharathi Publisher, 2005, Volume-II: 216 p.

6. Sharma P.V., Sushruta Samhita text with English translation and Dalhana's commentary, Reprinted edition, Varanasi, Chaukhambha Visvabharathi Publisher, 2005, Volume-II: 217 p.

7. Srikantha Murthy K.R., Sushruta Samhita text with English translation, Third edition, Varanasi, Chaukhambha Orientalia Publishers , 2007, VolumeI: $122 \mathrm{p}$.

8. Thatte D.G., Sushruta Samhita text with English translation, IInd edition, Varanasi, Chaukhambha Orientalia Publisher, 2007, Volume-III: 140 p.

9. D.G.Thatte, Sushruta Samhita text with English translation, IInd edition, Varanasi, Chaukhambha Orientalia Publisher, 2007, Volume-III: 140 p.

10. Chaurasia B.D., Handbook of General Anatomy, IIIrd edition, New Delhi, CBS Publishers, 2000, $81 \mathrm{p}$

11. Thatte D.G., Sharira Rachana Vigyan, Ind edition, Varanasi, Chaukhambha Sanskrit Series Office,2008, 264 p.

12. Tortora and Angasontakos, Principles of Anatomy and Physiology, IVth edition, Newyork, Harper and Row Publishers, 1984, 482 p.

13. .Sharma P.V, Sushruta Samhita text with English translation and Dalhana's commentary, Reprinted edition, Varanasi, Chaukhambha Visvabharathi Publisher, 2005, Volume-II: 200 p.

14. Gananath Sen Saraswathi, Sanjna Pancake Vimarsha, Reprinted edition, Varanasi, Krishnadas Academy Publishers, 1993, 67 p. 
15. Srikantha Murthy K.R., Sushruta Samhita text with English translation, Third edition, Varanasi, Chaukhambha Orientalia Publishers, 2007, Volume-I: $125 \mathrm{p}$.

16. Ghanekar B.G., SushrutaSamhita Sarirasthanam, Reprinted edition, New Delhi, Meharchand lachhmandas Publications, 2002, 205p.

17. Sharma P.V., Sushruta Samhita text with English translation and Dalhana's commentary, Reprinted edition,
Varanasi, Chaukhambha Visvabharathi Publisher, 2005, Volume-II: 184 p.

18. Srikantha Murthy K.R., Sushruta Samhita text with English translation, Third edition, Varanasi, Chaukhambha Orientalia Publishers, 2007, Volume-I: $107 \mathrm{p}$.

19. Srikantha Murthy K.R., Sushruta Samhita text with English translation, Third edition, Varanasi, Chaukhambha Orientalia Publishers, 2007, Volume-I: $108 \mathrm{p}$. 